\title{
Introduction in Siberia (Russia) of new vegetable species with a high biochemical value
}

\author{
Y.V. Fotev ${ }^{1,2 *}$, A.I. Syso ${ }^{3}$, O.M. Shevchuk ${ }^{4}$ \\ ${ }^{1}$ Central Siberian Botanical Garden, SB RAS, Novosibirsk, Russia \\ ${ }^{2}$ Novosibirsk State Agrarian University, Novosibirsk, Russia \\ ${ }^{3}$ Institute of Soil Science and Agrochemistry, SB RAS, Novosibirsk, Russia \\ ${ }^{4}$ Nikita Botanical Garden RAS, Republic of Crimea, Russia
}

DOI 10.18699/ICG-PlantGen2019-01

(c) Autors, 2019

* e-mail: fotev_2009@mail.ru
Abstract: Considering the narrow range of the cultivated vegetable species in Russia and the worldwide trend for impoverishment of the biochemical composition of cultivated vegetables, simultaneously with globalization of the vegetable crop production, it is necessary to search for plant species and forms characterized by a high content of functional food ingredients (FFI) in their composition,. Based on the methodological approaches to the introduction of initial material and cultivars of warm-requiring vegetable plants (Fotev, 2018), cultivars, and selective forms of new for Russia vegetables characterized by a high content of $\mathrm{FFI}$, a short growing season and a neutral reaction to the day length have been developed: asparagus vigna, kiwano, bitter melon, wax gourd, Chinese broccoli, and fish mint. The selected species, cultivars and forms of vegetables can be used as functional foods (FF).

Key words: Introduction; asparagus vigna; kiwano; bitter melon; wax gourd; Chinese broccoli; fish mint; biochemical value.

\section{Introduction}

Archaeological data show that the food of the ancient people (the Acheulian culture, about $780 \mathrm{ka} \mathrm{BP}$ ) was characterized by a significant variety of plant food sources (Melamed, 2016), whereas the modern man receives about $75 \%$ of the food resources using only 12 plant species (FAO.ftp://ftp.fao. org/docrep/fao/007/y5609e/y5609e00.pdf). Among the fresh vegetables consumed by Russians, only 6 main crops - white cabbage, tomato, cucumber, carrots, table beet and onion - account for over $86 \%$ vegetables eaten (Ryzhkova, Silko, 2015). Besides, in the second half of the 20th century, a significant decline in the nutritional quality of agricultural products was reported. Within 50 years (1950-1999) in the USA, the Ca content in the group of 16 vegetable crops decreased by $23 \%$, $\mathrm{Fe}-$ by $27 \%$ (Davis et al., 2004). The reported rate of decrease in micronutrient concentration ranged from $0.2 \%$ to $0.3 \%$ per year. The changes that have occurred are global. In the soils and plants of the agrarian regions in the south of Siberia, Russia, the content of essential trace elements $(\mathrm{Co}, \mathrm{Cu}, \mathrm{Mo}$ and $\mathrm{Zn}$ ) has decreased, as compared with the biogeochemical norm (Syso et al., 2016). In addition, significant intraspecific variability in the content of vitamins and mineral elements has been reported. The climatic conditions of the south of western Siberia, characterized by the considerable input of solar radiation of about $100 \mathrm{kcal} / \mathrm{cm}^{2}$ per year and a significant number of hours of sunshine per year (2029), make cultivation of a wide range of species and varieties of warm-requiring vegetable plants possible. Recently, methodological approaches to the introduction of warm-requiring vegetable plants in Siberia (Fotev, 2018) and a concept of the Russian national system of functional foods have been proposed (Fotev et al., 2018). Given the narrow range of cultivated vegetable plant species in Russia and the worldwide trend of impoverishment of the biochemical composition of vegetables, simultaneously with globalization of the crop production, it is necessary to search for those species and forms of plants that are high in FFI in their composition.

\section{Materials and methods}

Research was conducted from 1996 to 2017 on a large collection of species and forms of warm-requiring vegetable plants in outdoor and indoor conditions in the Central Siberian Botanical Garden of the Siberian Branch of the Russian Academy of Sciences [CSBG SB RAS] (Novosibirsk, $54^{\circ} \mathrm{N} 83^{\circ} \mathrm{E}$ ). We used the collection of vegetable plants (UNU "Collection of living plants in indoor and outdoor conditions" No. USU 440534), including 134 species, 4 subspecies and 14 varieties belonging to 44 genera and 13 families, represented in the Genbank of seeds containing 10,754 samples. The main new for Russia species studied in the CSBG SB RAS were asparagus vigna (Vigna unguiculata (L.) Walp.), bitter melon (Momordica charantia L.), kiwano (Cucumis metuliferus E. Mey. ex Naudin), wax gourd (Benincasa hispida (Thunb.) Cogn.), fish mint (Houttuynia cordata Thunb.) and Chinese broccoli or kai-lan (Brassica oleracea L. var. alboglabra (L.H. Bailey) Musil.). The content of macroelements (K, Na, $\mathrm{Ca}, \mathrm{Mg}, \mathrm{Fe}$ ) in the seeds of $V$. unguiculata grown in CSBG SB RAS and Nikita Botanical Garden of the Russian Academy of Sciences (NBG RAS), the Republic of Crimea was determined by flame atomic absorption spectrometry (FAAS) on an Analyst400 spectrometer (PerkinElmer). Recommended methods of biochemical studies of plants were used (Ermakov, 1987).

\section{Results and discussion}

To select plant species to be introduced in Siberia and to make predictive evaluation of the results of working with them, a list of parameters was proposed: the biochemical composition, the 
Table 1

New for Russia vegetables, their main $\mathrm{FFI}^{*}$, the physiological effect on the human body (or animals) and the first cultivars created in Siberia

\begin{tabular}{|c|c|c|c|}
\hline Species & Main FFl's * & Physiological effects & $\begin{array}{l}\text { First in Russia } \\
\text { cultivars }\end{array}$ \\
\hline $\begin{array}{l}\text { Asparagus vigna } \\
\text { Vigna unguiculata (L.) Walp., } \\
\text { Fabaceae }\end{array}$ & $\begin{array}{l}\text { Ascorbic acid, carotenoids, trace elements } \\
\text { (Ca, Mg, Fe, Mo) (Fotev et al., 2013), } \\
\text { proteins, antioxidants, polyphenols, } \\
\text { chlorogenic acid, caffeic acid (Zia-Ul-Haq } \\
\text { et al., 2013) }\end{array}$ & $\begin{array}{l}\text { Antioxidant, antiradical effects (Zia-Ul-Haq } \\
\text { et al., 2013), accelerates the elimination of } \\
\text { harmful and radioactive substances (137Cs) } \\
\text { by } 29 \% \text { (Evtukhova et al., 2009) }\end{array}$ & $\begin{array}{l}\text { Sibirskiy razmer, } \\
\text { Yunnanskaya }\end{array}$ \\
\hline $\begin{array}{l}\text { Bitter melon } \\
\text { Momordica charantia L., } \\
\text { Cucurbitaceae }\end{array}$ & $\begin{array}{l}\text { Carotenoids, ascorbic acid, catechins, } \\
\text { pectins, trace elements (Fe, Zn, Mn, Cu, } \\
\mathrm{Ni}, \mathrm{Co} \text { ) (Fotev et al., 2013), glycoalkaloids } \\
\text { (momorcharins) (Wang et al., 2017). }\end{array}$ & $\begin{array}{l}\text { Antioxidant, antiviral effect, causes apoptosis } \\
\text { of cancer cells (Dandawate et al., 2016), hypo- } \\
\text { glycemic effect in diabetes (Jia et al., 2017). }\end{array}$ & Gosha \\
\hline $\begin{array}{l}\text { Kiwano } \\
\text { Cucumis metuliferus E. Mey, } \\
\text { Cucurbitaceae }\end{array}$ & $\begin{array}{l}\text { Trace elements (Mg, Zn, Cu) (Fotev et al., } \\
\text { 2013), flavonoids, in a small amount - } \\
\text { cucurbitacins (Aliero, Gumi, 2012). }\end{array}$ & $\begin{array}{l}\text { Anti-inflammatory effect, increases the } \\
\text { activity of enzymes - alkaline phosphatase, } \\
\text { aspartate amino-transferase and alanine- } \\
\text { aminotransferase, platelet cyclooxygenase } \\
\text { inhibition (Wannang et al., 2007). }\end{array}$ & Zeleniy drakon \\
\hline $\begin{array}{l}\text { Wax gourd Benincasa hispida } \\
\text { (Thunb.) Cogn., Cucurbita- } \\
\text { ceae }\end{array}$ & $\begin{array}{l}\text { Trace elements (Mn, } \mathrm{Fe}, \mathrm{Co}, \mathrm{Cu} \text { ) (Fotev et } \\
\text { al., 2013), triterpenes - alnusenol and } \\
\text { multiflorenol, sterols and glycosides (Zaini } \\
\text { et al., 2011). }\end{array}$ & $\begin{array}{l}\text { Antioxidant, antiallergic action (Park et al., } \\
\text { 2009), anti-ulcer effect (Rachchh, Jain, 2008), } \\
\text { used in the treatment of helminth infections } \\
\text { (Al-Snafi, 2013). }\end{array}$ & Akulina \\
\hline $\begin{array}{l}\text { Fish mint } \\
\text { Houttuynia cordata Thunb., } \\
\text { Saururaceae }\end{array}$ & $\begin{array}{l}\text { Ascorbic acid, trace elements (Co, Cu, Fe, } \\
\text { Mn, Zn) (Fotev et al., 2017), flavonoids and } \\
\text { other polyphenolic compounds, pyridine } \\
\text { alkaloids, aporphine, organic and fatty } \\
\text { acids, sterols (Fu et al., 2013). }\end{array}$ & $\begin{array}{l}\text { It is used in the treatment of a significant } \\
\text { number of human diseases, such as cardio- } \\
\text { vascular diseases, cancer, anemia, diabetes } \\
\text { mellitus, dysentery, etc. (Rathi et al., 2013). }\end{array}$ & \\
\hline $\begin{array}{l}\text { Chinese broccoli or kai-lan } \\
\text { Brassica oleracea L. var. al- } \\
\text { boglabra (L.H.Bailey) Musil., } \\
\text { Brassicaceae }\end{array}$ & $\begin{array}{l}\text { Ascorbic acid, trace elements (K, Ca, } \\
\text { Mg,Cu) (Fotev et al., 2018), antioxidants, } \\
\text { polyphenolic compounds, glucosinolates } \\
\text { (Wang et al., 2017). }\end{array}$ & $\begin{array}{l}\text { Antioxidant, anti-inflammatory, antimicrobial, } \\
\text { anti-carcinogenic effects (Cartea et al., 2010) }\end{array}$ & \\
\hline
\end{tabular}

* FFI - functional food ingredients

degree of genetic diversity of species, duration of the vegetation period, warmth demand, productivity, seed production efficiency, fruit quality, a need for growing seedlings, a need for glasshouse production, resistance to diseases and pests, simplicity and manufacturability of processing the products, conformity to traditional taste preferences of population of the Russian Federation (Fotev et al., 2009). New for Russia vegetables, their main FFI, their physiological effect on the human body (or animals) and first-breeding cultivars created in Siberia are shown in the table below.

The fruits of the first created in Russia cultivar of asparagus vigna Yunnanskaya contain $83.9 \mathrm{mg} \%$ of ascorbic acid. The fruits of selected bitter melon forms have a high content of carotenoids (in the arillus of the fruits 68.9-177, in leaves $350.8-545.1 \mathrm{mg} \%(\mathrm{FW})$ and of ascorbic acid (72.5$127.5 \mathrm{mg} \%)$. The high content of elements of the so-called "hematopoietic complex" (Fe, $\mathrm{Mn}, \mathrm{Cu}, \mathrm{Co}$ ): $\mathrm{Fe}$ 45.2-141.6, Mn 9.8-18.7, Cu 2.0-5.4 and Co 0.03-0.05 $\mu \mathrm{g} / \mathrm{g}$ was found in the fruits of cultivars and samples of bitter melon, kiwano and wax gourd (the respective content of these elements in the fruits of tomato, cultivar Delta 264 is, accordingly, 38.0; 7.8; 1.7 and $0.03 \mu \mathrm{g} / \mathrm{g}$ ). Increased concentrations of $\mathrm{Zn}$ in the fruits of bitter melon, asparagus vigna and kiwano $(32.9-57.6 \mu \mathrm{g} / \mathrm{g})$ were recorded, with the comparative content in tomato fruits being $18.5 \mu \mathrm{g} / \mathrm{g}$. The fruits of the selected forms of asparagus vigna accumulate an increased amount of Mo $(5,47 \mu \mathrm{g} / \mathrm{g})$. Kiwano and asparagus vigna fruits have a high $\mathrm{Mg}$ content. The leaves of the sample of Houttuynia cordata accumulated $\mathrm{Mn}, \mathrm{Fe}$, and $\mathrm{Cu}$, and the roots $-\mathrm{Fe}, \mathrm{Co}, \mathrm{Cu}$, and $\mathrm{Zn}$. The stem part of B. oleracea var. alboglabra (cv. "Siji Xianggu jie lan") is a fairly good source of vitamin $\mathrm{C}$, accumulating $32.0 \ldots$ $46.2 \mathrm{mg} \%$, also distinguished by increased concentration of $\mathrm{K}$, $\mathrm{Ca}, \mathrm{Mg}$ and $\mathrm{Cu}$. To isolate species and forms that are stable on the basis of accumulation of FFI, evaluation of the biochemical composition of plants grown under environmentally different conditions is necessary. The smallest variability $\left(\mathrm{C}_{\mathrm{v}}\right)$ of the content of 5 macroelements in the seeds $(\mathrm{K}, \mathrm{Na}, \mathrm{Ca}, \mathrm{Mg}, \mathrm{Fe})$ of 6 samples of asparagus vigna in the CSBG SB RAS and NBG RAS was observed in the cultivar Sibirskiy razmer $-14.6 \%$. In the future, it is promising to develop agrotechnologically advanced cultivars with a high FFI content. On the basis of biochemically valuable cultivars of asparagus vigna (Sibirskiy razmer and Yunnanskaya cultivars), symbiotic systems with strains of Bradyrhizobium sp., characterized by a high level of symbiotic nitrogen fixation, were created (Fotev et al., 2016). It is also important to study the presence and the amount 
of anti-nutrients (phytates, lectins, oxalates, tannins, some biogenic amines, etc.) in FFI source plants.

\section{Conclusions}

To select promising species and forms of vegetable plants in biochemical and nutritional terms, it is recommended to use a set of selection criteria describing the characteristics and properties which include, in addition to the high content of FFI, the possibility of implementing biochemical and productive qualities of the vegetables under conditions that differ from the natural habitat of the species.

The created cultivars and selected forms of new for Russia vegetables, like asparagus vigna, bitter melon, kiwano and wax gourd, have a high content of FFI, high productivity, a short growing season and a neutral response to the day length. Fish mint and Chinese broccoli cultivars, being also FF (FF - functional food), can be successfully grown in Siberia. Individual samples of asparagus cowpea, for example, cultivar Sibirskiy razmer are characterized by high stability of accumulation of macroelements in the phytomass.

The interest of the Russian consumers in healthy foods should naturally lead to accelerated creation of new varieties both by traditional breeding methods and new technologies based on genome editing.

\section{References}

Davis D.R., Epp M.D., Riordan H.D. Changes in USDA food composition data for 43 garden crops, 1950 to 1999. J. Amer. Coll. Nutr. 2004;23(6):669-682.

Fotev Y.V. Towards a methodology of introduction of warm-requiring vegetable plants in Siberia. Vestnik NGAU (Novosibirsk State Agrarian University). 2018;4:104-118. doi.org/10.31677/2072-6724-201849-4-104-118. https://vestngau.elpub.ru/jour/article/view/1094/578

Fotev Yu.V., Pivovarov V.F., Artemyeva A.M., Kulikov I.M., Goncharova Yu.K., Syso A.I., Goncharov N.P. Concept of producing of the Russian national system of functional food. Vavilov Journal of Genetics and Breeding. 2018;22(7):776-783. DOI 10.18699/ VJ18.421. http://www.bionet.nsc.ru/vogis/download/06 Fotev.pdf

Melamed Y., Kisleva M.E., Geffenb E., Lev-Yadunc S., Goren-Inbard N. The plant component of an Acheulian diet at Gesher Benot Ya'aqov, Israel. PNAS. 2016;113(51):14674-14679. DOI 10.1073/ pnas. 1607872113 .

Ryzhkova S.M., Silko E.A. The market for vegetable products in Russia. Bulletin OrelGAU. 2015;4(55):3-7. http://dx.doi.org/10.15217/ 48484.

Syso A.I., Miadelets M.A., Siromlya T.I., Petukhov V.L., Sokolov V.A. The current state and trends in the ecological-biogeochemical situation in the south of Siberia. In: Current trends in the development of biogeochemistry. M.: GEOKHI RAS, 2016:500-510.

Conflict of interest. The authors declare no conflict of interest. 